\title{
Isolasi Brucella abortus dari cairan higroma dan susu
}

\author{
Tri Handayani ${ }^{1, *}$, Susan Maphilindawati Noor ${ }^{2}$, Fachriyan Hasmi Pasaribu $^{3}$ \\ ${ }^{1}$ Laboratorium Kesehatan dan Reproduksi Ternak, Pusat Aplikasi Isotop dan Radiasi, Badan Tenaga Nuklir Nasional, \\ Jakarta \\ ${ }^{2}$ Divisi Bakteriologi, Balai Besar Penelitian Veteriner, Bogor \\ ${ }^{3}$ Departemen Ilmu Penyakit Hewan dan Kesehatan Masyarakat Veteriner, Fakultas Kedokteran Hewan, Institut \\ Pertanian Bogor, Bogor
}

\begin{abstract}
ABSTRAK: Brucella abortus merupakan salah satu bakteri penyebab keguguran pada ternak sapi. Sampel cairan higroma dan susu digunakan untuk screening keberadaan bakteri B. abortus dari ternak yang dicurigai menderita brucellosis. Tujuan dari penelitian ini adalah untuk memperoleh bakteri B. abortus dari sampel cairan higroma dan susu. Total 36 sampel cairan higroma dan susu diperoleh dari NTT dan Jawa barat. Sampel ditumbuhkan dalam media TSB dan TSA dengan $\mathrm{CO}_{2} 5 \%$. Hasil pemeriksaan menunjukkan morfologi koloni bakteri bulat, halus dan permukaan convex, hasil pewarnaan Gram menunjukkan bakteri gram negatif, coccobacillus dan memiliki kecenderungan sendiri-sendiri ataupun berpasangan. Uji biokimiawi katalase dan oksidase menunjukkan hasil positif, sedangkan uji sitrat negatif. Bakteri memerlukan penambahan $5 \% \mathrm{CO}_{2}$ dalam pertumbuhannya, memiliki kemampuan memproduksi $\mathrm{H}_{2} \mathrm{~S}$, dan urease serta tumbuh dengan keberadaan Basic Fuchin, tetapi tidak tumbuh di zat warna Thionin. Bakteri yang tumbuh tersebut diidentifikasi sebagai $B$. abortus. Total isolat B. abortus yang diperoleh pada penelitian ini adalah 16 isolat dari 36 sampel cairan higroma dan susu.

Kata kunci:

isolasi, Brucella abortus, cairan higroma, susu
\end{abstract}

\section{- PENDAHULUAN}

Bakteri Brucella abortus merupakan salah satu bakteri yang menyebabkan keguguran pada ternak (Quinn et al, 2002; Dereje et al, 2018). Penyakit yang disebabkan oleh bakteri Brucella sp. disebut brucellosis. Secara klinis keberadaan bakteri ini ditandai dengan abortus, retensi plasenta, orchitis, eididimitis, dan architis, namun hal tersebut jarang terjadi. Penyebaran bakteri dapat terjadi melalui ekskresi bakteri dari kotoran uterus dan susu. Selain itu manifestasi atau indikator umum di beberapa negara tropis adanya infeksi brucellosis adalah cairan higroma pada persendian (OIE, 2016). Penelitian ini bertujuan untuk memperoleh bakteri B. abortus dari cairan higroma dan susu.

\section{- BAHAN DAN METODE}

Total sampel yang digunakan pada penelitian sebanyak 36 sampel. Sampel diperoleh dari ternak sapi yang dicurigai menderita brucellosis di wilayah Belu dan TTU, Nusa Tenggara Timur dan Bogor, Jawa barat (Tabel 1). Teknik isolasi bakteri $B$. abortus dilakukan secara konvensional. Cairan higroma dimasukkan ke dalam tabung berisi media Tryptic Soy Broth (TSB) dengan penambahan Fetal Calf Serum (FCS) dan Brucella selective supplement. Selanjutnya sampel diinkubasi pada suhu $37^{\circ} \mathrm{C}$ selama 3 - 5 hari di inkubator $\mathrm{CO}_{2}$. Setelah terlihat kekeruhannya maka bakteri dikultur pada media yang mengandung Triptic Soy Agar (TSA) dan Brucella selective supplement dan diinkubasi selama 3 - 5 hari di inkubator $\mathrm{CO}_{2}$. Isolasi dilakukan berdasarkan metode Alton et al. (1988) dan OIE (2016). Selanjutnya dilakukan identifikasi bakteri meliputi morfologi koloni, pewarnaan Gram dan uji biokimiawi (oksidase, katalase dan uji sitrat), biotyping isolat terhadap penggunaan $\mathrm{CO}_{2}$, produksi $\mathrm{H}_{2} \mathrm{~S}$, aktifitas urease, pertumbuhan pada zat warna Basic fuchsin dan Thionin.

Tabel 1. Sampel cairan higroma, dan susu pada penelitian

\begin{tabular}{|l|l|l|c|}
\hline No & Sampel & Lokasi sampel & Jumlah \\
\hline 1 & Cairan Higroma & Belu dan TTU, NTT & 20 \\
2 & Susu & Bogor, Jawa Barat & 16 \\
\hline \multicolumn{3}{|r|}{ Jumlah } & $\mathbf{3 6}$ \\
\hline
\end{tabular}

\section{- HASIL DAN PEMBAHASAN}

Nusa Tenggara Timur (NTT) dan Jawa Barat merupakan daerah dengan populasi sapi yang relatif tinggi. Berdasarkan data Statistik Peternakan dan Kesehatan Hewan 2016 diketahui bahwa jumlah sapi potong di NTT tahun 2016 sebanyak 930.997 ekor, dan jumlah sapi perah di Jawa Barat 119.287 ekor. Pemilihan sampel di daerah Jawa barat berdasarkan ternak mempunyai riwayat keguguran, sedangkan sampel dari NTT berdasarkan

Diterima: 06-06-2018 | Direvisi: 03-07-2018 | Disetujui: 30-07-2018 (C) 2018 CC-BY-SA. Ini adalah artikel Open Access yang didistribusikan berdasarkan ketentuan dari Creative Commons Attribution ShareAlike 4.0 International License (https://creativecommons.org/licenses/by-sa/4.0/). 
adanya pembesaran bagian lutut pada ternak sapi. Tingkat kejadian brucellosis di Belu, NTT menunjukkan prevalensi mencapai 14,9\% (Lake, 2010). Pada kasus brucellosis kronis dapat terjadi radang persendian kaki yang biasanya akan terakumulasi cairan higroma. Penelitian ini, bakteri yang terisolasi sebagai $B$. abortus memiliki karakteristik yaitu morfologi koloni bulat, halus,licin, permukaan convex dan seperti setetes madu. Pewarnaan gram menunjukkan bakteri gram negatif, coccobacillus dan memiliki kecenderungan sendiri-sendiri ataupun berpasangan. Uji biokimiawi katalase dan oksidase menunjukkan hasil positif, sedangkan uji sitrat negatif. Bakteri memerlukan penambahan $5 \% \quad \mathrm{CO}_{2}$ dalam pertumbuhannya, memiliki kemampuan memproduksi $\mathrm{H}_{2} \mathrm{~S}$, dan urease serta tumbuh dengan keberadaan Basic Fuchin, tetapi tidak tumbuh di zat warna Thionin.

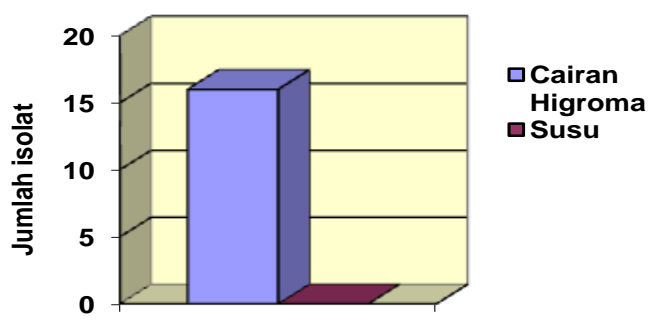

Gambar 1 Jumlah isolat Brucella abortus dari sampel cairan higroma dan susu.

Berdasarkan Gambar 1 isolat bakteri B. abortus yang diperoleh dari 20 sampel cairan higroma sebanyak 16 isolat. Sedangkan 16 sampel susu yang dilakukan analisis tidak diperoleh isolat bakteri $B$. abortus. Hasil penelitian ini sesuai pada penelitian dengan sampel susu dimana tidak didapatkannya isolat, tetapi isolat diperoleh dari membran dan liver fetus (Manthew et al, 2015). Studi pada 10 sampel cairan higroma diperoleh 10 isolat B. abortus (Chisi et al, 2017). Higroma merupakan salah satu sampel pilihan yang dapat digunakan dalam studi bakteriologi (Sanogo et $a l, 2013)$. Hasil penelitian lain didapatkannya 17 isolat $B$. abortus dari 360 sampel susu dan darah (Md. Sadequ et al, 2018), dan 11 isolat dari 217 sampel susu (Denis et al, 2015). Penelitian dengan sampel higroma dan susu pada hewan kerbau menunjukkan hasil negatif, tetapi isolat diperoleh dari sampel plasenta dan organ fetus (Kirit et al, 2017). Beberapa kemungkinan yang menyebabkan sampel susu tidak diperoleh isolat karena jumlah bakteri dalam sampel terlalu rendah, volume susu saat inokulasi atau kultur sedikit, eskresi bakteri dalam susu bersifat intermitent, faktor transportasi selama pengambilan sampel dan penyimpanan (Alton et al, 1988; Jennifer et al, 2012).

\section{- SIMPULAN}

Hasil isolasi 36 sampel cairan higroma dan susu diperoleh 16 isolat bakteri $B$. abortus dari sampel cairan higroma.

\section{- INFORMASI PENULIS}

Penulis untuk Korespondensi

* TH : trihanda@batan.go.id

PAIR PAIR BATAN, Jalan Lebakbulus Raya no 49 Jakarta Selatan.

\section{Kontribusi penulis}

TH menulis paper. SMN dan FP memberikan masukan pada paper. Semua penulis membaca dan menyetujui naskah akhir.

\section{- UCAPAN TERIMA KASIH}

Terima kasih kepada Mbak Shelyn dan Pak Agus dari IPB, Bapak Supartono dan Mbak Ira BBALITVET, Dokter John dari NTT dan PAIR BATAN yang telah memberikan dana untuk penelitian ini.

\section{- PUSTAKA ACUAN}

Alton GG, Jones LM, Angus RD, Vengr JM. 1988. Techniques for The Brucellosis Laboratory. Paris: Institute National De La Recherche Agronomique.

Chisi SL, Marageni Y, Naidoo P, Zulu G, Akol GW, Van Heerden H. 2017. An evaluation of serological tests in the diagnosis of bovine brucellosis in naturally infected cattle in KwaZulu-Natal province in South Africa. J S Afr Vet Assoc. 88(1): 1-7.

Denis RM, Shaman M, Sofia B, Joseph E, George WN, Charles W, Gerald M, Markus K, Ulf Magnusson. 2015. Isolation and molecular characterization of brucella isolates in cattle milk in Uganda. BioMed Research International. 2015:1-9.

Dereje T, Benti D, Feyisa B, Abiy G. 2018. Review of common causes of abortion in dairy cattle in Ethiopia. J Vet Med Anim Health. 10(1): 1-13.

Jennifer AZ, Maves RC, Nydam DV, Ayvar V, Cepeda D, Castillo R, Diaz-Pino A, Saito M, Gilman RH. 2012. Effect of storage temperature and sample volume on Brucella melitensis isolation from goat milk. Int J Tropical Dis Health. 2012: 207-213.

Kirit BP, HC Chauhan, BK Patel, SS Patel, MD Shrimali, JK Kala, SI Patel, AN Modi, AC Patel, Manish Rajgor, MA Patel, MG Patel, BS Chandel. 2017. Isolation, identification and molecular detection of Brucella abortus from buffaloes in Gujarat, India. Int J Curr Microbiol App Sci. 6(4): 1787-1795.

Lake, PRMT. 2010. Kajian Lintas Seksional Brucellosis pada Sapi di Kabupaten Belu. Tesis. Universitas Gadjah Mada.

Mathew C, M Stokstad, TB Johansen, S Klevar, RH Mdegela, G Mwamengele, P Michel, L Escobar, D Fretin, J Godfroid. 2015. First isolation, identification, phenotypic and genotypic characterization of Brucella abortus biovar 3 from dairy cattle in Tanzania. BMC Veterinary Research. 11(1):156.

Md. Sadequl I, Md. Ariful I, Mst. Minara K, Sukumar S, Md. Samiul B, Md. Mahmodul H. 2018. Molecular detection of Brucella spp. from milk of seronegative cows from some selected Aaea in Bangladesh. Journal of Pathogens 2018:1-7.

OIE. World Organization for Animal Health. 2016. Terrestrial Mannual. Chapter 2.1.4. Brucellosis. www.oie.int.

Quinn PJ, BK Markey, ME Carter, WJ Donnelly, FC Leonard. 2002. Veterinary Microbiology and Microbial Disease. Blackwell publishing. 162-167.

Sanogo M, Abatih, Eric Thys , Fretin D, Berkvens D, Saegerman C. 2013. Importance of identification and typing of brucella from west African cattle: A review. Veterinary Microbiology 164(3-4): 202-211. 